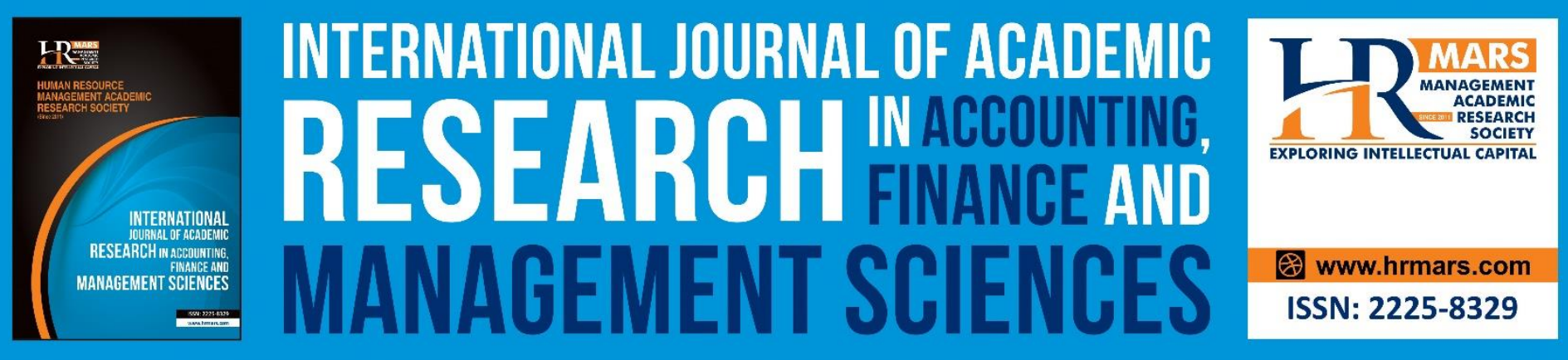

\title{
Employees' Behavioral Intention to Adopt E-HRM System- An Approach to Extend Technology Acceptance Model
}

\author{
Nishath Anjum \& Md. Afsarul Islam
}

To Link this Article: http://dx.doi.org/10.6007/IJARAFMS/v10-i3/8140

DOI:10.6007/IJARAFMS /v10-i3/8140

Received: 10 June 2020, Revised: 13 July 2020, Accepted: 16 August 2020

Published Online: 30 September 2020

In-Text Citation: (Anjum \& Islam, 2020)

To Cite this Article: Anjum, N., \& Islam, M. A. (2020). Employees' Behavioral Intention to Adopt E-HRM SystemAn Approach to Extend Technology Acceptance Model. International Journal of Academic Research in Accounting Finance and Management Sciences, 10(3), 544-561.

Copyright: (c) 2020 The Author(s)

Published by Human Resource Management Academic Research Society (www.hrmars.com)

This article is published under the Creative Commons Attribution (CC BY 4.0) license. Anyone may reproduce, distribute, translate and create derivative works of this article (for both commercial and non-commercial purposes), subject to full attribution to the original publication and authors. The full terms of this license may be seen

at: http://creativecommons.org/licences/by/4.0/legalcode

Vol. 10, No. 3, 2020, Pg. 544 - 561

http://hrmars.com/index.php/pages/detail/IJARAFMS

JOURNAL HOMEPAGE

Full Terms \& Conditions of access and use can be found at

http://hrmars.com/index.php/pages/detail/publication-ethics 


\title{
Employees' Behavioral Intention to Adopt E-HRM System- An Approach to Extend Technology Acceptance Model
}

\author{
Nishath Anjum \& Md. Afsarul Islam \\ Department of Business Administration, Metropolitan University, Sylhet, Bangladesh
}

\begin{abstract}
Purpose- This study aims to investigate the Information Technology (IT) sector employees' behavioral intention towards the adoption of Electronic Human Resource Management (E-HRM) with the help of the Technology Acceptance Model (TAM) in the context of Bangladesh.

Design/methodology/approach- The data for this study was collected through a structured questionnaire from 130 employees of IT sector in Bangladesh. The research model was developed based on the TAM theory with three external variables (organizational resources competency, organizational innovativeness and employee technical competency). The TAM theory extended by showing a direct relationship between organizational innovativeness and behavioral intention to adopt E-HRM. The data is analyzed by using SPSS 25 . Multiple regression analysis was employed to examine the predictors and their relationships with behavioral intention to adopt E-HRM.

Findings- The results of the study showed that the respondents have a positive intention towards adopting E-HRM system. All three external variables have different effects on perceived usefulness and perceived ease of use. Most of the relationships are quite significant. Moreover, a strong direct relationship was found between organizational innovativeness and behavioral intention regarding $\mathrm{E}$ HRM adoption.
\end{abstract}

Research limitations- The dearth of empirical studies and to better understand the factors that influence the intention of employees towards E-HRM adoption in organizations is the main limitation of the study. Thus it is suggested to use more representative variables with a greater sample size in further studies. The study also had a geographical limitation.

Practical implications- The research findings can provide an insight to all those business organizations who are planning to adopt E-HRM system and the human resource managers can use the results as an opportunity to develop HRM functions through E-HRM adoption.

Originality/value- This research contributes to the body of knowledge as it measures the employee intention towards E-HRM adoption by analyzing the influence of several factors thus enabling similar organizations to produce more vigorous proposals for E-HRM adoption.

Keywords: Electronic Human Resource Management (E-HRM), Behavioral Intention, Information Technology (IT), Technology Acceptance Model (TAM) 
INTERNATIONAL JOURNAL OF ACADEMIC RESEARCH IN ACCOUNTING, FINANCE AND

MANAGEMENT SCIENCES

Vol. 10 , No. 3, 2020, E-ISSN: $2225-8329$ @ 2020 HRMARS

\section{Introduction}

The adoption of information and communication technology (ICT) has brought a significant change in the management of business activities as well as in management records and procedures (Winarto, 2017; Strohmeier, 2007). Over the last decade adopting and using of ICTs by Human resource management (HRM) departments have found a common phenomenon referred as E-HRM (Gloet and Berrell, 2003). In general, E-HRM consists of all applications of labor force planning, supply and demand forecast, staffing information, applicant tracking, information on training and development, salary management, employee relations, promotion related information and so on (Bamel et al., 2014). E-HRM is gaining importance gradually and the use of web-based technologies for human resource management practices is increasing within organizations (Lin et al., 2011; Ruel et. al., 2004). Recently, human resource (HR) departments in many organizations in the developed countries have improved their performance by employing E-HRM systems (Hosain and Rahman, 2016). Conversely, in the context of developing countries (e.g. Bangladesh, India, Nepal and Pakistan), E-HRM research and its application is still limited (Bondarouk et al., 2017; Johnson et al., 2016). In Bangladesh, a few large companies have started to implement E-HRM in the last few years (Jahan, 2014). The majority of the HR processes are becoming automated especially the functions related to administration (Mukherjee, 2001) but many organizations are still failing to realize the benefits of E-HRM and have taken no or a very little initiative to implement such environment (Samaduzzaman and Zaman, 2012). However, there are some organizations attempted to implement E-HRM systems and faced significant challenges (Johnson et al., 2016; Heikkila et al., 2014) such as, the lack of skilled workforce, unavailability of sophisticated IT infrastructure and lack of organizational innovativeness (Simon and Esteves, 2016; Jaradat, 2013). Moreover, the employees also often try to resist new technology and the organization is likely to be unable to overcome the resistance of staff who do not perceive the usefulness of the technology (Chen et al., 2010; Ho, 2010; Cakmak et al., 2011; Bondarouk et al., 2017). Thus, the success of the organization does not solely depend upon the adoption of the E-HRM but also to understand the intention of employees towards adoption of the technology (Simon and Esteves, 2016; Al-Dmour and Shannak, 2012). The acceptability of a particular technology or system can be better understood through Technology Acceptance Model (TAM) by Davis (1989). The model helps in analyzing the behavioral intention of employees by considering the two internal factors as the perceived usefulness and the perceived ease of use on the basis of the attitude of the employees while using the technology (Dosajh and Sujlana, 2012). This research looks forward to understand the intention of IT sector employees in Bangladesh towards adoption of E-HRM by using the Technology Acceptance Model (TAM).

\section{Research Objectives}

The study objectives are as follows-

1. To understand the behavioral intention of IT sector employees in Bangladesh to adopt E-HRM system.

2. To explore the factors influencing IT sector employees' E-HRM adoption intention in Bangladesh.

3. To investigate the relationship between organizational innovativeness and adoption intention of E-HRM system. 
INTERNATIONAL JOURNAL OF ACADEMIC RESEARCH IN ACCOUNTING, FINANCE AND

MANAGEMENT SCIENCES

Vol. 10 , No. 3, 2020, E-ISSN: $2225-8329$ @ 2020 HRMARS

\section{Literature Review}

\section{Electronic Human Resource Management (E-HRM)}

E-HRM is the administrative support of the HR function in an organizations by using the internet technology (Voermans and van Veldhoven, 2007). It supports the organization in managing all the information related to HR electronically (Johnson et al., 2016; Ruel, et al., 2004). E-HRM as a part of management information system supports and helps in the planning process, administration process, decision making process and controlling the HRM activities (Bal et al., 2012; Lengnick-Hall and Moritz, 2003). The major functions of E-HRM are E-recruiting, E-selection, E-training, E-learning, Ecompensation management, E-performance appraisal, E-Employee Profile, E-Leave etc. (Dhamija, 2012; Armstrong, 2016; Stone and Gueutal, 2005; Parry, 2011; Hendrickson, 2003). E-HRM can possibly influence both efficiency and effectiveness of HR function (Bondarouk et al., 2017; Cedarcrestone, 2005; Aggarwal and Kapoor, 2012). The positive outcome of E-HRM includes reducing costs, speeding up processes, improving productivity and quality, reducing paperwork, increasing data accuracy, diminishing HR staff, improved communication, better decision making and even gaining a more strategic role for HR within the organization (Lengnick Hall et al., 2003; Thite et al., 2012; Wiblen et al., 2010). Other benefits of E-HRM includes developing better work culture with more transparent management system, reduction of administrative burden, ensuring decentralization and standardization of HR tasks and encouraging self-managed work teams etc. (Hosain, 2015; Rodriguez and Ventura, 2003).

\section{Employee Technical Competency (ETC)}

Employee Technical Competency refers to the required practical knowledge and skills to do specific job or group of jobs within the organization. In case of E-HRM adoption, employee must need the skills to run and operate the system (Esen and Ozbag, 2014). E-HRM applications are not only used by the employees of HR department but also by other employees of the organization to keep track of their personal HR operations (Oswal and Narayanappa, 2015). Thus, the usage proficiency of ICT by workers gains more attention in the field of E-HRM (Wright, 2008). On the other hand, due to the insufficient knowledge and skills of operating E-HRM function, many organizations have faced difficulties (Guechtouli, 2010). Perhaps, the HR managers' lack of practical knowledge and proper training on E-HRM functions generated low utility in developing countries (Samaduzzaman et al., 2015; Al-Dmour et al., 2012). Lack of IT competencies also force employees to resist in using and adopting new technology which has been highlighted as a significant issue in case of E-HRM adoption (Weekes, 2006; Hustad and Munkvold, 2005).

\section{Organizational Innovativeness (OIN)}

Organizational innovativeness refers to accept new ideas or doing something unique or receptive about new way of doing things or transferring and applying a new thought to business activities (Ruel et al., 2004; Hurley and Hult, 1998). Basically, E-HRM is the combination of traditional HR practices along with modern equipped computer-network systems. So, adoption of E-HRM system considered to be an innovation approach by business organizations (Parry and Wilson, 2009). Thus, IT adoption is ultimately influenced by the institutional intention of innovativeness (Bal etal., 2012; Strohmeier et al., 2009). E-HRM consists of some new applications for organizations which may include number of technological tools and software in the achievement of HRM activities (Lopez and Masson, 1997; 
INTERNATIONAL JOURNAL OF ACADEMIC RESEARCH IN ACCOUNTING, FINANCE AND MANAGEMENT SCIENCES

Vol. 10, No. 3, 2020, E-ISSN: 2225-8329 ๔ 2020 HRMARS

Hong et al., 2008; Ho, 2010). It was found that enterprises which are innovative and open to change are more fascinated in adopting E-HRM system than other organizations (Museum et al., 2015; Carlson and O'Cass 2010).

\section{Organizational Resources Competency (ORC)}

Organizational resources such as software, hardware, technical infrastructure and financial resources found to be an essential element to perform the functions of E-HRM (Hooi, 2006; Cardy and Miller, 2005; Sanjeev and Makkar, 2014). The cost of E-HRM implementation, technical support fitting the requirement, software and hardware maintenance are considered the most important resources for E-HRM adoption (Reddick, 2009; Islam, 2016). In absence of the supportive resources, the workers might encounter difficulties which may negatively affect their intention regarding the adoption of IT (Igbaria et al., 1997; Schaupp et al., 2010). On the other hand, lack of organizational infrastructure may cause discomfort and anxiety among individuals which may prevent the adoption of technology (Sandberg and Wahlberg, 2006). According to Mathieson and Chin (2001), IT usage level is more on those organizations which have satisfactory amount of resources than other organizations.

\section{Technology Acceptance Model (TAM)}

Technology Acceptance Model (TAM) was developed by Fred Davis in the year of 1989. Throughout the edges, TAM became one of the major influential extensions of Ajzen and Fishbein's Theory of Reasoned Action (TRA). Mostly this theory is employed to know how general folks are perceived the technology or information system and their behavioral intention to accept and use of that specific technology or information system. According to Venkatesh (2000), TAM is widely used for understanding the users' behavioral intention to accept and use of specific technology or information system. Hence, Perceived Usefulness (PU) was defined as "the degree to which a person believes that using a particular system would enhance his or her job performance" and Perceived ease-of-use (PEOU) was defined as "the degree to which a person believes that using a particular system would be free from effort" and the Behavioral intention to use indicates an individual's willingness to try or how much he or she is determined about accepting new technology or innovation (Davis, 1989). From TAM, behavioral intention towards a new technology acceptance by an individual jointly influenced by perceived usefulness and perceived ease of use. Besides, the TAM hypothesizes a direct link between perceived usefulness and perceived ease of use which depicts that a user will find more useful the technology that he or she finds easier to use and at the same time, if the user finds the new technology required less effort or easy functioning then he or she will consider the new technology as useful (Bueno and Salmeron, 2008).

\section{Relationship among the Research Variables}

Employee technical competency has a positive relationship with adoption of E-HRM system in an organization. If the employees are not competent enough to use the technology, it will be much harder for them to understand its usefulness and thus adopt it properly (Bamel et al., 2014; Armstrong et al., 2005). Similarly, positive relationship is found between the use of electronic systems and organizational innovativeness (DA, 2019; Foster and Cornford, 1992). Organizational innovation has a direct and strong influence on the behavioral intention to adopt specific technology (Agag, G. et al., 2016; Hahn, et al., 2014). Thus, innovative culture of the organization has positive impact on perceived usefulness, perceived ease of use and behavioral intention to use a new technology (Chung 
INTERNATIONAL JOURNAL OF ACADEMIC RESEARCH IN ACCOUNTING, FINANCE AND MANAGEMENT SCIENCES

Vol. 10, No. 3, 2020, E-ISSN: 2225-8329 @ 2020 HRMARS

et al., 2015; Parry et al., 2009; Oswal et al., 2015). Apparently, organizational resource competency seems to be an important factor in case of IT adoption (Oswal and Narayanappa, 2015). The perception of the adequacy of the institutional resources positively affects perceived usefulness, perceived ease of use and behavioral intention to adopt of E-HRM applications or system (Hooi, 2006). According to Esen and Ozbag (2014), organizational resource competency, organizational innovativeness and employee technical competency all have a significant and positive effect on each TAM variables (perceived ease of use, perceived usefulness and behavioral intention to use). A significant number of researchers have found that perceived ease of use has positive effect on perceived usefulness (Venkatesh and Davis, 2000; Mun et al., 2006; Fu et al., 2006; Lee et al., 2007). Individuals should believe E-HRM applications became usefulness to them due to free of effort and easy functioning (Gallego et al., 2008; Tung and Chang, 2008; Esen and Özbağ, 2014). Moreover, it is found that both perceived usefulness and perceived ease of use has positive effect on behavioral intention to use E-HRM practices in organizations in the future (Hong and Tam, 2006; Lee et al., 2006; Tung and Chang, 2008; Ghorbani et al., 2011).

\section{Proposed Research Model}

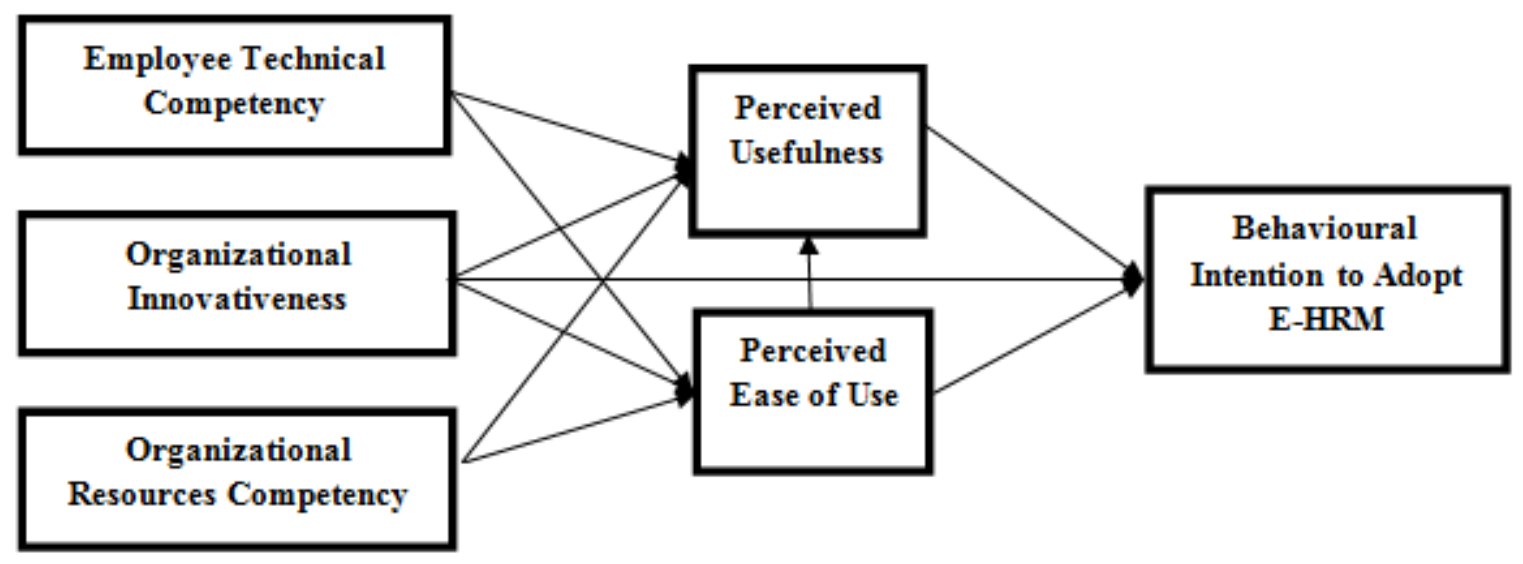

\section{Research Method}

\section{Data Sources and Sample}

The results are mainly based on primary data. Secondary sources has been used to construct the literature and other theoretical parts. The data for this study was collected by structured questionnaire through random sampling from the employees of IT sector of Bangladesh. A total of 157 questionnaires were distributed and after screening all questionnaires we have got 130 complete and usable questionnaires. Consequently, valid questionnaires were $82.8 \%$ of the total respondents for this study.

\section{Questionnaire}

The questionnaire was segmented into two parts, where the first part followed by the demographic factors of the respondents and second part consists of both the independent and dependent variables of this study. To measure the opinion of the respondents regarding E-HRM adoption, all items were measured through using a 5-point Likert-type scale from 1 ('strongly disagree') to 5 ('strongly agree'). 


\section{Research Model}

This study is based upon TAM theory. The three external variables (Extracted from literature review) used in the model are Employee Technical Competency (ETC), Organizational Innovativeness (OIN) and Organizational Resource Competency (ORC). These three variables directly linked with Perceived Usefulness (PU) and Perceived Ease of Use (PEOU) and also PU and PEOU linked with the behavioral intention to adopt E-HRM system. The TAM theory extended by showing a direct relationship of Organizational Innovativeness (OIN) with behavioral intention to adopt E-HRM. The proposed research model split into four models. In the first model, PU is denoted as dependent variable whereas ETC, OIN and ORC are respectively considered as independent variables. In model 2, PEOU is considered as dependent variable and ETC, OIN and ORC are respectively considered as independent variables. In model 3, PU is dependent variable and PEOU is independent variable. In model $4, \mathrm{BI}$ is dependent variable while PU, PEOU and OIN are respectively followed as independent variables.

\section{Analysis}

Data analysis was carried out with SPSS 25 version software. First, Principal Component Factor Analysis was carried out to test the reliability of the questionnaire. Secondly, descriptive statistics done through using demographic variables. Thirdly, Correlation were computed for all independent and dependent variables to assess the internal relationships among variables. Finally, multiple regression analysis was employed to measure the significant effect of independent variable (s) on dependent variable.

\section{Hypothesis of the Study}

$\mathrm{H} 1_{1}$ : Employee Technical Competency has positive impact on Perceived Usefulness.

$\mathrm{H}_{2}$ : Organizational Innovativeness has positive impact on Perceived Usefulness.

$\mathrm{H}_{1}$ : Organizational Resource Competency has positive impact on Perceived Usefulness.

$\mathrm{H} 2_{1}$ : Employee Technical Competency has positive impact on Perceived Ease of Use.

$\mathrm{H}_{2}$ : Organizational Innovativeness has positive impact on Perceived Ease of Use.

$\mathrm{H}_{2}$ : Organizational Resource Competency has positive impact on Perceived Ease of Use.

H3: Perceived Ease of Use has positive effect on Perceived Usefulness.

H4: Perceived Usefulness has positive and significant effect on Behavioral Intention.

H5: Perceived Ease of Use has positive and significant effect on Behavioral Intention.

H6: Organizational Innovativeness has positive and significant effect on Behavioral Intention. 


\section{Data Analysis and Findings}

Table 1: Descriptive Statistics

Demographics

Gender
Age
Level of
Education
Employment
Type

Job Experience

\section{Categories \\ Male}

Female

Less than 20 Years

21- 24 Years

25-29 Years

30-34 Years

35 Years or more

Post-Graduation or more

Graduation

Under Graduation

Government

Semi Government

Autonomous

Private

Less than one Year

2 to 3 Years

4 to 5 Years

6 Years or more

\section{Frequency}

102

28

16

44

46

17

07

56

69

5

19

13

9

89

22

48

42

20
Percent

78.46

21.54

12.30

33.84

35.38

13.08

5.38

43.07

53.08

03.85

14.61

10.00

6.92

68.46

16.92

36.92

32.30

15.38

Table 1, demonstrates the respondents' demographic profile of this study. The number of male respondents (78.46\%) were higher than female respondents $(21.54 \%)$. In terms of age, the majority of the respondents were from $25-29$ years old (35.38\%). Whereas, less than 20 years were $12.30 \%$, 21- 24 years were $33.84 \%, 30-34$ years were $13.08 \%$ and finally, 35 years or more were $5.38 \%$. On the other hand, most of the respondents came from graduate background $(53.08 \%)$, then post graduate (43.07\%) and lastly under graduate (3.85\%). In this study, majority of the respondents were from private sector IT organizations (68.46\%), then from government sector (14.61\%), semi government sector (10.00\%) and autonomous sector (6.92\%). Finally, in terms of the respondents' experience of doing the job, mostly were from 2 to 3 years constituting 36.92\%, the percentage of 4 to 5 years were $32.30 \%$, less than one year were $16.92 \%$ and 6 years and more were $15.38 \%$.

\section{Table 2: Reliability Test (Summary of the Cronbach's Alpha)}

\section{Variables}

Employee Technical Competency

Organizational Innovativeness

Organizational Resource Competency

Perceived Usefulness

Perceived Ease of Use

Behavioral Intention

\section{Number of Items}

3

3

3

5

5

3
Cronbach Alpha ( $\alpha$ )

.700

.726

.837

.800

.775

.738 
INTERNATIONAL JOURNAL OF ACADEMIC RESEARCH IN ACCOUNTING, FINANCE AND MANAGEMENT SCIENCES

Vol. 10, No. 3, 2020, E-ISSN: 2225-8329 @ 2020 HRMARS

Table 2, depicts the reliability test of the study. Here, six sets of reliability test were run and showed the Alpha value of different constructs and the number of items used for each construct to get the standard Cronbach's Alpha value (>0.70). The table shows, Cronbach's Alpha $(\alpha)$ values for Employee Technical Competency, Organizational Innovativeness, Organizational Resource Competency, Perceived Usefulness, Perceived Ease of Use and Behavioral Intention were respectively as .700, .726, $.837, .800, .775$ and .738 which are $(\alpha)>0.70$. Which ensures that the reliability or internal consistency of the survey questions are acceptable for this study.

Table 3: Pearson Correlation Analysis

\begin{tabular}{|c|c|c|c|c|c|c|}
\hline & $\overline{B I}$ & PEOU & $\overline{P U}$ & $\overline{E T C}$ & ORC & OIN \\
\hline BI & 1 & & & & & \\
\hline PEOU & $.498^{* *}$ & 1 & & & & \\
\hline PU & $.518^{* *}$ & $.612^{* *}$ & 1 & & & \\
\hline ETC & $.492^{* *}$ & $.479^{* *}$ & $.693^{* *}$ & 1 & & \\
\hline ORC & $.567^{* *}$ & $.417^{* *}$ & $.617^{* *}$ & $.688^{* *}$ & 1 & \\
\hline OIN & $.373^{* *}$ & $.467^{* *}$ & $.284^{* *}$ & $.188^{*}$ & $.359^{* *}$ & 1 \\
\hline $\begin{array}{l}* * \text { Correlat } \\
{ }^{*} \text { Correlati }\end{array}$ & $\begin{array}{l}\text { significa } \\
\text { ignificar }\end{array}$ & $\begin{array}{l}\text { the } 0.01 \\
\text { he } 0.05\end{array}$ & $\begin{array}{l}\text { (2-taile } \\
\text { 2-tailec }\end{array}$ & & & \\
\hline
\end{tabular}

Table 3, represents the corrections among all the constructs of this study. The result revealed that behavioral intention has positive correlation with perceived ease of use $\left(.498^{* *}\right)$ or $49.8 \%$ at 99 percent confident interval and significant at the 0.01 level (.000). On the other hand, behavioral intention also positively correlated with other constructs respectively as perceived usefulness $\left(.518^{* *}\right.$ or $\left.51.8 \%, .000\right)$, employee technical competency $\left(.492^{* *}\right.$ or $\left.49.2 \%, .000\right)$, organizational resource competency $\left(.567^{* *}\right.$ or $\left.56.7 \%, .000\right)$ and organizational innovativeness $\left(.373^{* *}\right.$ or $37.3 \%$, $.000)$. In addition, perceived ease of use is positively correlated with perceived usefulness $\left(.612^{* *}\right.$ or $61.2 \%, .000)$, employee technical competency $\left(.479^{* *}\right.$ or $\left.47.9 \%, .000\right)$, organizational resource competency $\left(.417^{* *}\right.$ or $\left.41.7 \%, .000\right)$ and organizational innovativeness $\left(.467^{* *}\right.$ or $\left.46.7 \%, .000\right)$. Moreover, perceived usefulness positively correlated with employee technical competency $\left(.693^{* *}\right.$ or $69.3 \%, .000)$, organizational resource competency $\left(.617^{* *}\right.$ or $\left.61.7 \%, .000\right)$ and organizational innovativeness $\left(.284^{* *}\right.$ or $\left.28.4 \%, .000\right)$. Besides, employee technical competency has positive association with organizational resource competency $\left(.688^{* *}\right.$ or $\left.68.8 \%, .000\right)$ and organizational innovativeness $\left(.188^{*}\right.$ or $\left.18.8 \%, .000\right)$. Finally, organizational resource competency is positively associated with organizational innovativeness $\left(.359^{* *}\right.$ or $\left.35.9 \%, .000\right)$. 
INTERNATIONAL JOURNAL OF ACADEMIC RESEARCH IN ACCOUNTING, FINANCE AND MANAGEMENT SCIENCES

Vol. 10, No. 3, 2020, E-ISSN: 2225-8329 @ 2020 HRMARS

Table 4: Regression Analysis

Model Summary

\begin{tabular}{|c|c|c|c|c|c|c|c|c|c|c|}
\hline \multirow[b]{2}{*}{ Model } & \multirow[b]{2}{*}{$R$} & \multirow[b]{2}{*}{$\begin{array}{c}\mathrm{R} \\
\text { Square }\end{array}$} & \multirow[b]{2}{*}{$\begin{array}{c}\text { Adjusted } \\
\text { R } \\
\text { Square }\end{array}$} & \multicolumn{2}{|l|}{ Std. } & \multicolumn{3}{|c|}{ Change Statistics } & \multirow[b]{2}{*}{ Sig. $F$} & \multirow[b]{2}{*}{$\begin{array}{l}\text { Durbin- } \\
\text { Watson }\end{array}$} \\
\hline & & & & $\begin{array}{c}\text { Error of } \\
\text { the } \\
\text { Estimate }\end{array}$ & $\begin{array}{c}\text { R } \\
\text { Square } \\
\text { Change }\end{array}$ & $\begin{array}{c}\mathrm{F} \\
\text { Change }\end{array}$ & df1 & $\mathrm{df} 2$ & & \\
\hline 1 & .726 & .527 & .516 & .505 & .527 & 46.861 & 3 & 126 & .000 & 1.686 \\
\hline 2 & .614 & .377 & .362 & .556 & .377 & 25.372 & 3 & 126 & .000 & 1.351 \\
\hline 3 & .612 & .374 & .369 & .574 & .374 & 77.173 & 1 & 129 & .000 & 1.694 \\
\hline 4 & .588 & .346 & .331 & .666 & .346 & 22.238 & 3 & 126 & .000 & 1.974 \\
\hline
\end{tabular}

Table 4, depicts the model summary of this study. The first regression model shows a good fit with $\mathrm{F}$ value $46.861(p<.05)$ and $R$ Square value of .527 indicating $52.7 \%$ of the variation in the perceived usefulness by the independent variables (Employee Technical Competency, Organizational Innovativeness and Organizational Resource Competency). Second model of this study demonstrates also a statistically significant model, whereas ( $F$ value $25.372, p<.05$ ) and result of $R^{2}$ change of $37.7 \%$ $\left(\Delta R^{2}=.377\right)$. Additionally, third model of this study seems significant with (F value $\left.77.173, p<.05\right)$ and $\mathrm{R}^{2}$ value of $37.4 \%\left(\Delta \mathrm{R}^{2}=.374\right)$. Finally, fourth model of this study, shows an overall significant model ( $(F$ value $22.238, p<.05)$ and $R$ Square value of .346 does indicates $34.6 \%$ of the variation in the behavioral intention to adopt E-HRM can be explained by the following independent variables (perceived usefulness, perceived ease of use and organizational innovativeness).

Table 5: ANOVA

$\begin{array}{ccccccc}\text { Model } & & \text { Sum of Squares } & \mathbf{d f} & \text { Mean Square } & \mathbf{F} & \text { Sig. } \\ \mathbf{1} & \text { Regression } & 35.828 & 3 & 11.943 & 46.861 & .000 \\ & \text { Residual } & 32.112 & 126 & .255 & & \\ \mathbf{2} & \text { Total } & 67.940 & 129 & & & \\ & \text { Regression } & 23.503 & 3 & 7.834 & 25.372 & .000 \\ & \text { Residual } & 38.907 & 126 & .309 & & \\ \mathbf{3} & \text { Total } & 62.410 & 129 & & & .000 \\ & \text { Regression } & 25.443 & 1 & 25.443 & 77.173 & \\ & \text { Residual } & 42.529 & 129 & .330 & & .000 \\ & \text { Total } & 67.971 & 130 & & & \\ & \text { Regression } & 29.623 & 3 & 9.874 & 22.238 & \\ & \text { Residual } & 55.947 & 126 & .444 & & \end{array}$

Table 5, represents ANOVA which means the general significance of the studied model (s). In this study we have employed four models and the $p$ value of all models denoted as $(0.000)$ which is much smaller than 0.05 or $5 \%$ level of significance. Therefore we can say that, all the models for this study have passed the test of model fit or level of significance. 
INTERNATIONAL JOURNAL OF ACADEMIC RESEARCH IN ACCOUNTING, FINANCE AND MANAGEMENT SCIENCES

Vol. 10, No. 3, 2020, E-ISSN: 2225-8329 @ 2020 HRMARS

Table 6: Summary of Coefficients

\section{Coefficients}

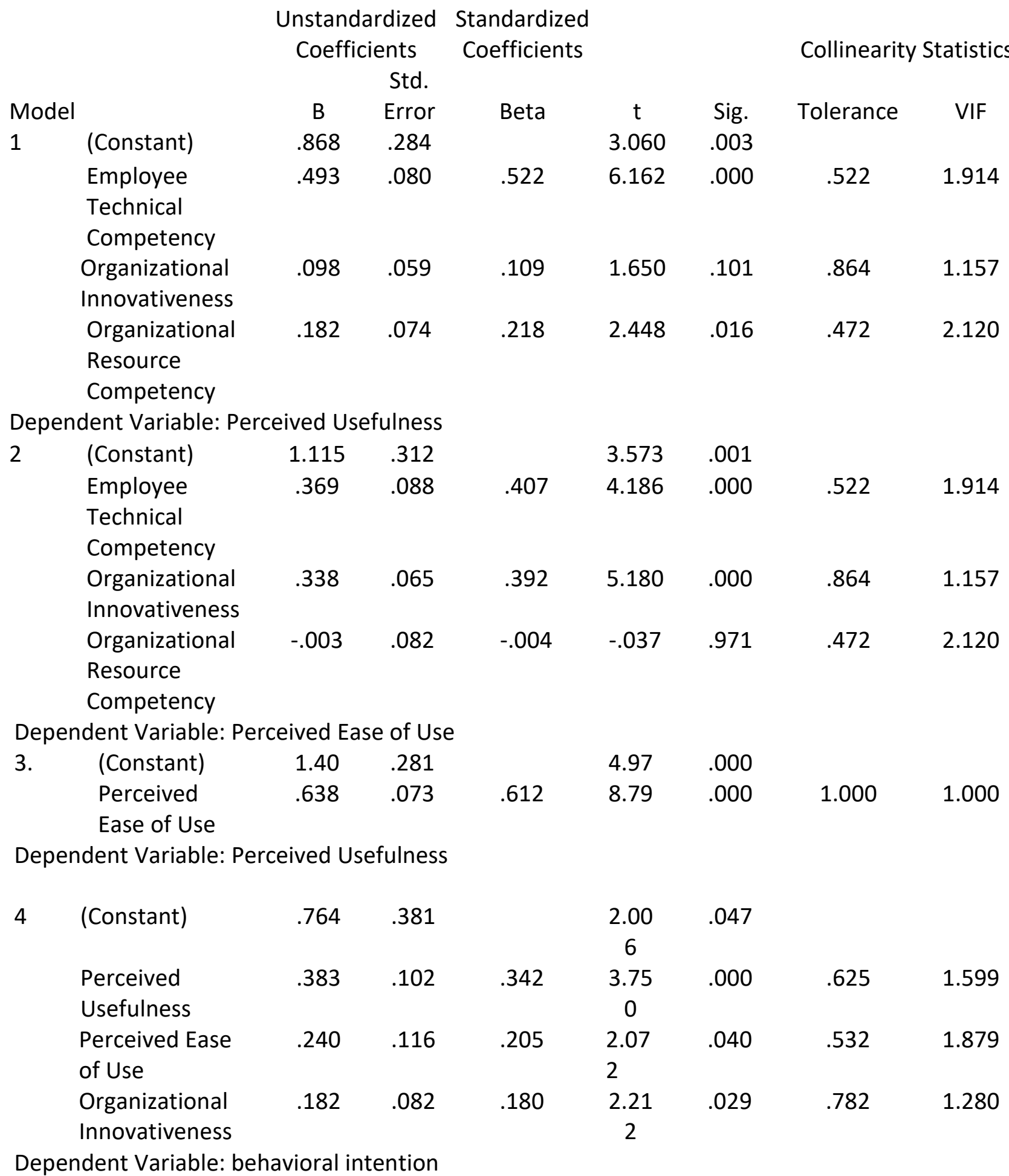

Table 6, demonstrates the summary of the coefficients of this study. Whereas model 1 depicts, the relationship between employee technical competency and perceived usefulness has found 
INTERNATIONAL JOURNAL OF ACADEMIC RESEARCH IN ACCOUNTING, FINANCE AND MANAGEMENT SCIENCES

Vol. 10, No. 3, 2020, E-ISSN: 2225-8329 @ 2020 HRMARS

statistically significant $(B=.522, t=6.162, \mathrm{p}=0.000<0.05)$. So, $\mathrm{H} 1_{1}$ is accepted. On the other hand, organizational innovativeness $(b=.109, t=1.650, p=.101>0.05)$ and organizational resource competency $(b=.218, t=2.448, p=.016<0.05)$ respectively have relationships with perceived usefulness. In this regard $\mathrm{H}_{2}$ is not accepted but $\mathrm{H}_{3}$ is accepted. In case of model 2, employee technical competency $(B=.407, t=4.186, p=0.000<0.05)$ and organizational innovativeness $(B=.392$, $t=5.180, \mathrm{p}=0.000<0.05)$ has found statistically significant. Therefore, hypothesis $\mathrm{H} 2{ }_{1}$ and $\mathrm{H} 22_{2}$ are supported for this study. Apparently, organizational resource competency $(b=-.004, t=-.037, p=.971$ $>0.05$ ) has found negative effect on perceived ease of use and no statistical significance. So, hypothesis $\mathrm{H}_{2}$ is not supported. For model 3 , perceived ease of use $(b=.612, t=8.79, \mathrm{p}=0.000<0.05)$ has found statistically significance with perceived usefulness. Thus, hypothesis $\mathrm{H} 3$ is accepted. In context of model 4 , all independent constructs perceived usefulness $(B=.342, t=3.750, p=0.000$ $<0.05)$, perceived ease of use $(b=.205, t=2.072, p=.040<0.05)$ and organizational innovativeness $(b=$ $.180, t=2.212, p=.029<0.05)$ have positive and significant relationship with behavioral intention to adopt E-HRM. Hence, hypothesis $\mathrm{H} 4, \mathrm{H} 5$ and $\mathrm{H} 6$ are accepted.

\section{Discussion}

This study aims to investigate the IT sector employees' adoption intention of Electronic Human Resource Management (E-HRM) in Bangladesh with the help of Technology Acceptance Model (Davis, 1989). Output of the study helps to cross check the established hypothesis and to make clear conception over the relationships among perceived usefulness (PU), perceived ease of use (PEOU), organizational innovativeness (OIN) and behavioral intention (BI) to adopt E-HRM in Bangladesh. Based on the output of this study, it was found that employee technical competency and organizational resource competency has positive and significant effect on perceived usefulness. Which seems similar to the prior research findings of (Esen and Özbağ, 2014). On the other hand, this study failed to prove the hypothesis between organizational innovativeness and perceived usefulness. This result seems alike to the research work of Lee (2020). This is different from findings of earlier studies. To justify the insignificant relationship, we can say that, usefulness of a technology may not always encourage the organization to be innovative (Martin, Alexander, Reddington, and Pate, 2006).

This study also confirmed that employee technical competency has a statistical significant relationship with perceived ease of use. This result is consistent with the result of (Esen and Özbağ, 2014). This study also established that, there is a positive and significant relationship between perceived ease of use and organizational innovativeness. This result also support prior research findings between organizational innovativeness and perceived ease of use (Lee, 2020). Moreover, output of the study showed that there is no significant relationship between organizational resource competency and perceived ease of use. This finding is dissimilar to the finding of (Esen and Özbağ, 2014). To justify the insignificant relationship, we can say that, as the study conducted on IT sector organization which are already technologically well equipped with IT trained employees so, the respondents may not feel any interconnection between organizational resource competencies with perceived ease of use.

Besides, it was found that perceived ease of use has significant relationship with perceived usefulness. This result has found similar to those of previous research works (Thiruselvi et al., 2013; Erdogmus and Esen, 2011; Lee, 2020). In addition, this study analysis verified that perceived 
INTERNATIONAL JOURNAL OF ACADEMIC RESEARCH IN ACCOUNTING, FINANCE AND MANAGEMENT SCIENCES

Vol. 10 , No. 3, 2020, E-ISSN: 2225-8329 @ 2020 HRMARS

usefulness and perceived ease of use has significant effect on behavioral intention to adopt E-HRM. Former studies had proved the same result (Erdogmus and Esen, 2011; Esen and Özbağ, 2014; Thiruselvi et al., 2013).

Furthermore, analysis of this study also confirmed that organizational innovativeness has a significant effect on behavioral intention to adopt E-HRM system. This hypothesis was supported by the studies (Lin et al., 2020; Kin et al., 2018). With regard to the effects of perceived usefulness, perceived ease of use and organizational innovativeness on E-HRM adoption intention, analysis showed that perceived usefulness has higher significant effect on E-HRM adoption intention than organizational innovativeness and perceived ease of use. This study also confirmed that organizational innovativeness has greater significant impact on adoption intention of E-HRM by IT sector employees rather than perceived ease of use.

\section{Conclusion}

E-HRM improves HR efficiency and influence HR strategy in any organization. This study takes an initial step to validate the intention towards adopting E-HRM by means of TAM. The findings of this study will help organizations to understand the employees' intention towards the adoption of E-HRM and all the studied variables are important determinants in terms of improving E-HRM adoption. Most importantly, perceived usefulness, perceived ease of use and behavioral intention to use are critical in E-HRM adoption. In order to make users continue the usage of E-HRM in their organizations, management should look into how to make it useful and easy to use for the employees. This will change the users' intention toward the acceptance and continuance usage of the system. In concluding this paper, it can be said that since intention influences technology adoption, organizations should be aware of this relationship when initiating information system. In other words, organizations must adopt their strategy to increase technology acceptance on the basis of users' preferences. However, this study investigated a limited number of variables to elucidate employee intention towards adopting E-HRM system. Future research is required to uncover other new variables of E-HRM adoption in the different industry settings by using well-designed research model(s). The study has been conducted on Bangladesh and may bring different types of result in case of other developing countries. Although there are some limitations, it is hoped that the first step taken in studying E-HRM adoption intention in this study is significant for further justification.

\section{Research Contribution}

This research paper has proposed a set of factors based on TAM which influences the intention towards E-HRM adoption. The proposed research model tried to extend TAM and explore the relationships of the research variables with behavioral intention to adopt E-HRM. The addition of these variables (Organizational Resource Competency, Organizational Innovativeness and Employee Technical Competency) in the theory will contribute significantly in organizational decisions as they are very important for current phenomena in case of E-HRM adoption. This will definitely advance the existing knowledge.

On the other hand, many organizations in Bangladesh and other countries are facing several difficulties and resistance in E-HRM adoption. Most of them have no sufficient knowledge about the preparedness to adopt new technology on HRM functions. The variables used in this study are very important to convince the user to adopt and use E-HRM. Thus, it has important implications for 
INTERNATIONAL JOURNAL OF ACADEMIC RESEARCH IN ACCOUNTING, FINANCE AND

MANAGEMENT SCIENCES

Vol. 10, No. 3, 2020, E-ISSN: 2225-8329 @ 2020 HRMARS

managing E-HRM platforms within the organization. Managers and trainers must take note of the findings of this study and design their E-HRM adoption strategy accordingly. This will promote the welfare of both individuals and organizations.

\section{References}

Agag, G., \& El-Masry, A. A. (2016). Understanding consumer intention to participate in online travel community and effects on consumer intention to purchase travel online and WOM: An integration of innovation diffusion theory and TAM with trust. Computers in human behavior, 60, 97-111.

Aggarwal, N., \& Kapoor, M. (2012). Human resource information systems (HRIS)-Its role and importance in business competitiveness. Gian Jyoti E-Journal, 1(2), 1-13.

Al-Dmour, R. H., \& Shannak, R. O. (2012). Determinants of the implementation level of electronic human resources management (E-HRM) in Jordanian shareholding companies. European Scientific Journal, 8(17), 204-235.

Armstrong, B., Fogarty, G. J., Dingsdag, D., \& Dimbleby, J. (2005). Validation of a computer user satisfaction questionnaire to measure IS success in small business. Journal of Research and Practice in Information Technology, 37(1), 27-42.

Bal, Y., Bozkurt, S., \& Ertemsir, E. (2012). The importance of using human resources information systems (HRIS) and a research on determining the success of HRIS.

Bamel, N., Bamel, U. K., Sahay, V., \& Thite, M. (2014). Usage, benefits and barriers of human resource information system in universities. VINE: The journal of information and knowledge management systems.

Bondarouk, T., Parry, E., \& Furtmueller, E. (2017). Electronic HRM: four decades of research on adoption and consequences. The International Journal of Human Resource Management, 28(1), 98-131.

Cakmak, A. F., Benk, S., \& Budak, T. (2011). The acceptance of tax office automation system (VEDOP) by employees: factorial validation of Turkish adapted Technology Acceptance Model (TAM). International Journal of Economics and Finance, 3(6), 107-116.

Cardy, R. L., \& Miller, J. S. (2005). E-HR and performance management: A consideration of positive potential and the dark side. The brave new world of eHR: Human resources management in the digital age, 138-165.

Carlson, J., \& O'Cass, A. (2010). Exploring the relationships between e-service quality, satisfaction, attitudes and behaviours in content-driven e-service web sites. Journal of services marketing.

Chen, Y. Y., Huang, H. L., Hsu, Y. C., Tseng, H. C., \& Lee, Y. C. (2010). Confirmation of expectations and satisfaction with the Internet shopping: The Role of Internet self-efficacy. Computer and Information Science, 3(3), 14

Chung, N., Han, H., \& Joun, Y. (2015). Tourists' intention to visit a destination: The role of augmented reality (AR) application for a heritage site. Computers in Human Behavior, 50, 588-599.

Crestone, C. (2005). The Cedar Crestone 2005 workforce technologies and service delivery approaches survey. 8th Annual Edition, 8(8).

DA, G. N. (2019). Relationship of Innovation Characteristics on Adoption of Consumer E-Banking in the Context of Top Three Private Commercial Banks in Sri Lanka. ICBI 2019, Kelaniya, 17 October, viewed 21 September 2019. 
INTERNATIONAL JOURNAL OF ACADEMIC RESEARCH IN ACCOUNTING, FINANCE AND

MANAGEMENT SCIENCES

Vol. 10, No. 3, 2020, E-ISSN: 2225-8329 @ 2020 HRMARS

Davis, F. D. (1989). Perceived usefulness, perceived ease of use, and user acceptance of information technology. MIS quarterly, 319-340.

Dhamija, P. (2012). E-recruitment: a roadmap towards e-human resource management. Researchers World, 3(3), 33.

Dosajh, B., \& Sujlana, P. (2012). New e-HRM Model Based on Technology Acceptance Model. Gian Jyoti E-Journal, 1(2), 1-10.

Erdogmus, N., \& Esen, M. (2011). An investigation of the effects of technology readiness on technology acceptance in e-HRM. Procedia-Social and Behavioral Sciences, 24, 487-495.

Esen, M., \& Ozbag, G. K. (2014). An investigation of the effects of organizational readiness on technology acceptance in e-HRM applications. International Journal of Human Resource Studies, 4(1), 232.

Fishbein, M., \& Ajzen, I. (1977). Belief, attitude, intention, and behavior: An introduction to theory and research.

Foster, D., \& Cornford, T. (1992). Evaluation of health information systems: Issues, models and case studies, social implications of computers in developing countries.

Fu, J. R., Farn, C. K., \& Chao, W. P. (2006). Acceptance of electronic tax filing: A study of taxpayer intentions. Information \& Management, 43(1), 109-126.

Gallego, M. D., Luna, P., \& Bueno, S. (2008). User acceptance model of open source software. Computers in Human behavior, 24(5), 2199-2216.

Ghorbani, H., \& Madani, F. A. (2011). An Empirical Investigation of the Determinants of User Acceptance of Electronic Exchanges (Case Study: Buying and Selling Section of Active Companies of Iran's Textile Industry). International Journal of Marketing Studies, 3(2), 73.

Gloet, M., \& Berrell, M. (2003). The dual paradigm nature of knowledge management: implications for achieving quality outcomes in human resource management. Journal of knowledge management.

Guechtouli, M. (2010). E-HRM's Impact on an Environmental Scanning Process: How Can Technology Support the Selection of Information?. International Journal of Technology and Human Interaction (IJTHI), 6(3), 53-66.

Hahn, S. S., Yoon, J. H., \& Kim, J. M. (2014). Extending the technology acceptance model to examine the intention to use tourism applications on smartphone. Korean Academy Society of Hospitality Administration, 23(3), 19-40.

Heikkila, J. P., Brewster, C., \& Mattila, J. (2014). Micro-political conflicts and institutional issues during e-HRM implementation in MNCs: A vendor's view. In Human Resource Management and Technological Challenges (pp. 1-21). Springer, Cham.

Hendrickson, A. R. (2003). Human resource information systems: Backbone technology of contemporary human resources. Journal of Labor Research, 24(3), 381-394.

Ho, C. H. (2010). Continuance intention of e-learning platform: Toward an integrated model. International Journal of Electronic Business Management, 8(3), 206.

Hong, S. J., \& Tam, K. Y. (2006). Understanding the adoption of multipurpose information appliances: The case of mobile data services. Information systems research, 17(2), 162-179.

Hong, S., Kim, J., \& Lee, H. (2008). Antecedents of use-continuance in information systems: Toward an inegrative view. Journal of Computer Information Systems, 48(3), 61-73. 
INTERNATIONAL JOURNAL OF ACADEMIC RESEARCH IN ACCOUNTING, FINANCE AND

MANAGEMENT SCIENCES

Vol. 10, No. 3, 2020, E-ISSN: 2225-8329 @ 2020 HRMARS

Hooi, L. W. (2006). Implementing e-HRM: The readiness of small and medium sized manufacturing companies in Malaysia. Asia Pacific Business Review, 12(4), 465-485.

Hosain, S. (2015). Adoption of Proper HRM Practices: A Technique for Retaining Employees and Increasing Firm Performance? Scholar Journal of Business and Social Science, 1(1), 1-14.

Hosain, S., \& Rahman, M. D. (2016). Green human resource management: A theoretical overview. IOSR Journal of Business and Management (IOSR-JBM) Volume, 18.

Hurley, R. F., \& Hult, G. T. M. (1998). Innovation, market orientation, and organizational learning: an integration and empirical examination. Journal of marketing, 62(3), 42-54.

Hustad, E., \& Munkvold, B. E. (2005). IT-supported competence management: A case study at Ericsson. Information Systems Management, 22(2), 78-88.

Igbaria, M., Zinatelli, N., Cragg, P., \& Cavaye, A. L. (1997). Personal computing acceptance factors in small firms: a structural equation model. MIS quarterly, 279-305.

Islam, M. (2016). Evaluating the practices of electronic human resources management (E-HRM) as a key tool of technology driven human resources management function in organizations-a comparative study in public sector and private sector enterprises of Bangladesh. IOSR Journal of Business and Management (IOSR-JBM), 18(11).

Jahan, S. S. (2014). Human resources information system (HRIS): a theoretical perspective. Journal of Human Resource and Sustainability Studies, 2014.

Jaradat, N. (2013). Electronic human resource management: issues and challenges in jordanian universities. Interdisciplinary Journal of Contemporary Research in Business, 4(12), 685-710.

Johnson, R. D., Lukaszewski, K. M., \& Stone, D. L. (2016). The evolution of the field of human resource information systems: Co-evolution of technology and HR processes. Communications of the Association for Information Systems, 38(1), 28.

Kim, D. J., Hebeler, J., Yoon, V., \& Davis, F. (2018). Exploring determinants of semantic web technology adoption from IT professionals' perspective: Industry competition, organization innovativeness, and data management capability. Computers in Human Behavior, 86, 18-33.

Lee, Y., Lee, J., \& Lee, Z. (2006). Social influence on technology acceptance behavior: self-identity theory perspective. ACM SIGMIS Database: the DATABASE for Advances in Information Systems, 37(2-3), 60-75.

Lee, J. (2020). Environmental Factors of Acceptance Organization Affecting Intention to Accept Bim. International Journal of Management, 11(4).

Lee, K. C., Kang, I., \& Kim, J. S. (2007). Exploring the user interface of negotiation support systems from the user acceptance perspective. Computers in human behavior, 23(1), 220-239.

Lee, M. C. (2010). Explaining and predicting users' continuance intention toward e-learning: An extension of the expectation-confirmation model. Computers \& Education, 54(2), 506-516.

Lengnick-Hall, M. L., \& Moritz, S. (2003). The impact of e-HR on the human resource management function. Journal of labor research, 24(3), 365-379.

Lin, J., Luo, Z., \& Luo, X. (2020). Understanding the roles of institutional pressures and organizational innovativeness in contextualized transformation toward e-business: Evidence from agricultural firms. International Journal of Information Management, 51, 102025.

Lin, L. H. (2011). Electronic human resource management and organizational innovation: the roles of information technology and virtual organizational structure. The International Journal of Human Resource Management, 22(02), 235-257. 
INTERNATIONAL JOURNAL OF ACADEMIC RESEARCH IN ACCOUNTING, FINANCE AND

MANAGEMENT SCIENCES

Vol. 10, No. 3, 2020, E-ISSN: 2225-8329 @ 2020 HRMARS

Lopez, D. A., \& Manson, D. P. (1997). A study of individual computer self-efficacy and perceived usefulness of the empowered desktop information system.

Martin, G., Alexander, H., Reddington, M., \& Pate, J. M. (2006). Using technology to transform the future of HR: an illustrated model of e-HR. In 2006 Academy of Management Annual Meeting.

Masum, A. K. M., Kabir, M. J., \& Chowdhury, M. M. (2015). Determinants that influencing the adoption of E-HRM: An empirical study on Bangladesh. Asian Social Science, 11(21), 117.

Mathieson, K., Peacock, E., \& Chin, W. W. (2001). Extending the technology acceptance model: the influence of perceived user resources. ACM SIGMIS Database: the DATABASE for Advances in Information Systems, 32(3), 86-112.

Mukherjee, A. (2007). HR transformation: can technology help?: IT talk. HR Highway, 1(4), 19-21.

Mun, Y. Y., Jackson, J. D., Park, J. S., \& Probst, J. C. (2006). Understanding information technology acceptance by individual professionals: Toward an integrative view. Information \& Management, 43(3), 350-363.

Oswal, M. N., \& Narayanappa, G. L. (2015). Evolution of HRM to E-HRM to achieve organizational effectiveness and sustainability. International Journal of Business Administration and Management Research, 1(2), 22-26.

Parry, E. (2011). An examination of e-HRM as a means to increase the value of the HR function. The International Journal of Human Resource Management, 22(05), 1146-1162.

Parry, E., \& Wilson, H. (2009). Factors influencing the adoption of online recruitment. Personnel Review.

Reddick, C. G. (2009). Human resources information systems in Texas City governments: Scope and perception of its effectiveness. Public Personnel Management, 38(4), 19-34.

Reddick, C. G. (2009). The adoption of centralized customer service systems: A survey of local governments. Government Information Quarterly, 26(1), 219-226.

Rodríguez, J. M., \& Ventura, J. (2003). Human resource management systems and organizational performance: an analysis of the Spanish manufacturing industry. The International Journal of Human Resource Management, 14(7), 1206-1226.

Ruel, H. J., Bondarouk, T. V., \& Van der Velde, M. (2007). The contribution of e-HRM to HRM effectiveness. Employee relations.

Ruël, H., Bondarouk, T., \& Looise, J. K. (2004). E-HRM: Innovation or irritation. An explorative empirical study in five large companies on web-based HRM. Management revue, 364-380.

Samaduzzaman, M., \& Zaman, F. (2012). E-HRM in Bangladesh. IOSR Journal of Business and Management, 4(6), 32-36.

Samaduzzaman, M., Zaman, F., \& Quazi, Z. (2015). Literature review on corporate governance structure and performance in non-financial firms in Bangladesh. Asian Journal of Finance \& Accounting, 7(1), 96.

Sandberg, K. W., \& Wahlberg, O. (2006). Towards a model of the acceptance of information and communication technology in rural small businesses. Department of Information Technology and Media, Mid Sweden University, SE-851, 70.

Sanjeev, R., \& Makkar, D. (2014). Determining employees' perception through effective hris: An empiricAl stuDy. Journal of Strategic Human Resource Management, 3(3).

Schaupp, L. C., Carter, L., \& McBride, M. E. (2010). E-file adoption: A study of US taxpayers' intentions. Computers in Human Behavior, 26(4), 636-644. 
INTERNATIONAL JOURNAL OF ACADEMIC RESEARCH IN ACCOUNTING, FINANCE AND

MANAGEMENT SCIENCES

Vol. 10, No. 3, 2020, E-ISSN: 2225-8329 @ 2020 HRMARS

Simón, C., \& Esteves, J. (2016). The limits of institutional isomorphism in the design of e-recruitment websites: a comparative analysis of the USA and Spain. The International Journal of Human Resource Management, 27(1), 23-44.

Stone, D. L., \& Gueutal, H. (2005). The brave new world of e-HR: Human resources management in the digital age. San Francisco: Jossy Boss.

Strohmeier, S. (2007). Research in e-HRM: Review and implications. Human resource management review, 17(1), 19-37.

Strohmeier, S., \& Kabst, R. (2009). Organizational adoption of e-HRM in Europe: An empirical exploration of major adoption factors. Journal of Managerial Psychology, 24(6), 482-501.

Thiruselvi, S., Yusliza, M. Y., Ramayah, T., \& Nur Zahitah, O. (2013). Continuance intention usage towards e-HRM. Proceedings Book of ICEFMO, Handbook on the Economic, Finance and Management Outlooks, 674-687.

Thite, M. O. H. A. N., Kavanagh, M. J., \& Johnson, R. D. (2012). Evolution of human resource management and human resource information systems. INTRODUCTION TO HUMAN RESOURCE MANAGEMENT, 2-34.

Tung, F. C., \& Chang, S. C. (2008). A new hybrid model for exploring the adoption of online nursing courses. Nurse Education Today, 28(3), 293-300.

Tung, F. C., \& Chang, S. C. (2008). Nursing students' behavioral intention to use online courses: A questionnaire survey. International journal of nursing studies, 45(9), 1299-1309.

Venkatesh, V., \& Davis, F. D. (2000). A theoretical extension of the technology acceptance model: Four longitudinal field studies. Management science, 46(2), 186-204.

Venkatesh, V., Morris, M. G., Davis, G. B., \& Davis, F. D. (2003). User acceptance of information technology: Toward a unified view. MIS quarterly, 425-478.

Voermans, M., \& Van Veldhoven, M. J. P. M. (2007). Attitude towards E-HRM: an empirical study at Philips. Personnel review.

Walczuch, R., Lemmink, J., \& Streukens, S. (2007). The effect of service employees' technology readiness on technology acceptance. Information \& Management, 44(2), 206-215.

Weekes, S. (2006). The six thorns in e-HR's side. Personnel Today. In focus. Reed Business Information UK. Sutton-UK. Retrieved from http://search.proquest.com/docview/229912209/12E8638CF9B22257208.

Wiblen, S. L., Grant, D., \& Dery, K. (2010). Transitioning to a new HRIS: The reshaping of human resources and information technology talent.

Winarto, W. (2018). Electronic Human Resources Management (E-HRM) adoption studies: past and future research. DeReMa (Development Research of Management): Jurnal Manajemen, 13(1), 100-120.

Yusoff, Y. M., Ramayah, T., \& Ibrahim, H. (2010). E-HRM: A proposed model based on technology acceptance model. African Journal of Business Management, 4(14), 3039-3045. 